\title{
THE INFLUENCE OF TEMPERATURE UPON THE TRANSPARENCY OF SOLUTIONS.
}

\author{
By Edward L. Nichols and Mary C. Spencer.
}

$\mathrm{T}^{\mathrm{H}}$

HE experiments to be described in this paper deal with the transparency of certain aqueous solutions, for various wavelengths of the visible spectrum and at temperatures ranging between $20^{\circ}$ and $80^{\circ} \mathrm{C}$. For the purposes of these measurements the horizontal slit photometer was used. The instrument was mounted upon a track, at the ends of which two similar incandescent lamps were placed. These lamps were so adjusted as to give as nearly as possible the same quality of light, and in front of one of them, at the observer's right hand, was placed a cell containing the solution to be tested. In Fig. I, which shows the

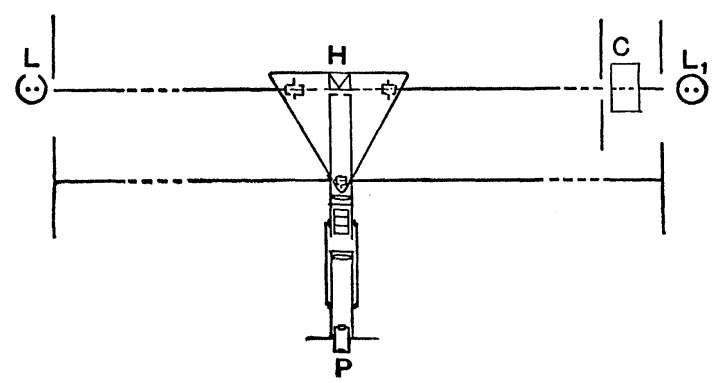

Fig. 1.

arrangement of the apparatus, $L$ and $L_{1}$ are the lamps, $C$ is the cell containing the solution, and $H P$ is the spectrophotometer. ${ }^{1}$

Figure 2 gives a cross-section of the cell used for heating the solutions, the transmitting power of which was to be tested. It consisted of a cylinder of brass about $15 \mathrm{~cm}$. in diameter. This

1 For a description of the horizontal-slit photometer see Transactions of the American Institute of Electrical Engineers, 1890; also Physical Review, Vol. 2, p. I38. 
cylinder was provided with broad flanges on either end, against which sheets of thin plate glass were securely clamped. A neck in the top of the cylinder allowed of the introduction of the solution and also of the insertion of a thermometer. The distance between the outer faces of the cell was $8.9 \mathrm{~cm}$., and the thickness of the contained layer of liquid $8.5 \mathrm{~cm}$.

The cell was heated by means of an electric current which traversed a coil of wire surrounding the brass cylinder. This coil is not shown in the diagram.

The method of procedure was as follows :-

The observing telescope of the photometer was set so as to bring a given

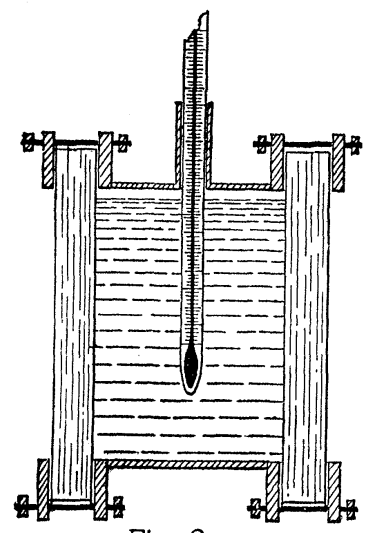
Fig. 2. portion of the visible spectrum into the field of view, and readings were made of the positions upon the bar at which the region under inspection was equally bright in the spectra of the two lamps. The cell containing the solution was then interposed and the light ratio was redetermined. A series of readings was taken in this way for the wave-length in question, the temperature of the solution being varied from time to time. The results of these observations were then indicated by means of a curve in which ordinates represented transmitting powers and abscissas temperatures, and the process was repeated until a series of such curves, for different regions of the spectrum, had been obtained. From these it was possible to derive the data for the construction of other curves showing the relative distribution of energy in the absorption spectrum of the solution at any desired temperature within the range covered by the experiment.

It is evident that the method just outlined will give much more definite and precise information concerning the influence of temperature upon the transparency of a solution than it is possible to obtain by means of the methods pursued by previous observers. Although a considerable amount of information upon this subject 
had already been massed by Gladstone, ${ }^{1}$ Melde, ${ }^{2}$ Hartley, ${ }^{3}$ Conroy, ${ }^{4}$ and others, all of whom agree in the general statement that temperature lessens the power of transmitting light, no one, so far as the present writers are aware, had undertaken to determine quantitatively, wave-length by wave-length, degree by degree, the exact amount of this decrease. This, by means of the apparatus just described, the writers have been able to do in the case of a considerable number of solutions.

The solutions tested were for the most part colored salts dissolved in distilled water, the concentration being such as to allow an easily measurable quantity of light to be transmitted, but at the same time to show distinctly the character of the selective absorption, where such existed. An equally important field, that of the study of the influence of temperature upon colorless solutions possessing definite absorption bands of great density (as, for example, the solutions of the salts of the rare earths), was not included in our investigation.

Several modes of expressing the results obtained by the method just indicated suggest themselves. One may, for example, give the transmitting power of the cell containing each of the solutions studied, in terms of that of the same cell when filled with distilled water and subjected to the same temperature changes; or, having determined the loss by reflection and by absorption within the glass walls of the cell, one may reduce the transparency in each case to that of a layer of unit thickness. For the purposes of the present investigation it was deemed sufficient to give the transmission of the filled cell in each case, since it was the comparison of the transmitting power of the solution when cold with that which it possessed at higher temperatures which was desired.

The substances tested were distilled water and aqueous solutions, chiefly of various salts. These, grouped according to their behavior when heated, are given in the following list :-

\footnotetext{
1 Gladstone, Philosophical Magazine (4), Vol. I4, p. 423.

2 Melde, Annalen der Physik und Chemie, Vol. I26, p. 284.

${ }^{3}$ Hartley, Proceedings of the Royal Society, Vol. 22, p. 24 I.

${ }^{4}$ Conroy, Philosophical Magazine (5), Vol. 31, p. 37 I.
} 
(A) $\left\{\begin{array}{l}\text { Cobalt-ammonium sulphate, } \\ \text { Potassium bichromate. }\end{array}\right.$ Potassium bichromate.

(C) $\left\{\begin{array}{l}\text { Distilled water, } \\ \text { Cochineal, } \\ \text { Sodium nitrate, } \\ \text { Nickel sulphate }\end{array}\right.$ Nickel sulphate.
Potassium chromate,

Sodium bichromate,

(B) Copper sulphate,

Chromic sulphate,

Potassium ferric cyanide.

(D) $\left\{\begin{array}{l}\text { Copper acetate, } \\ \text { Ferric chloride, } \\ \text { Potassium permanganate, } \\ \text { Copper chloride, } \\ \text { Nickel chloride. }\end{array}\right.$

Measurements at a single temperature were also made with the empty cell interposed between the spectrophotometer and the source of light, with results which are given in Table I.

TABLE I.

TRANSPARENCY OF THE EMPTY CELL.

\begin{tabular}{|c|c|c|c|c|}
\hline Wave-length & $0.6867 \mu$ & 0.5896 & $0.4700 \mu$ & $0.4080 \mu$ \\
\hline Transmission & 0.709 & 0.763 & 0.783 & 0.785 \\
\hline
\end{tabular}

Experiments upon the substances of Group $C$ having shown the influence of heat upon the transmitting power of the filled cell to be inappreciable, it was deemed unnecessary to make measurements with the empty cell at high temperatures.

The quantity denoted by the term "transmission" in the above, and in all subsequent tables, is the ratio of the light reaching the photometer through the cell to that which reaches the instrument directly when the cell is withdrawn.

The results of our measurements upon the solutions of the preceding list are contained in the following tables, and they are indicated graphically in some cases by means of the two species of diagram already referred to.

The first of these is an isochromatic curve showing the change in transmitting power of a single wave-length with varying temperature; the other is an isothermal curve by means of which the distribution of transparency in the visible spectrum is given for a single temperature. 
It will be seen from the following tables that the solutions tested fall naturally into the four groups already given :-

(I) Solutions suffering temporary change of transmitting power throughout the spectrum when heated (Group A).

(2) Solutions suffering temporary decrease of transparency in certain regions, but not throughout the entire spectrum (Group B).

(3) Liquids unaffected as regards transparency by temperature changes up to $80^{\circ}$ (Group C).

(4) Solutions suffering permanent change of color as the result of heating (Group D). Such solutions do not return to their original condition when cooled.

Measurements upon Group D were made only for a single region of the spectrum. It will be seen that as a rule they suffer diminution of transmitting power with rise of temperature. This sometimes occurs continuously, but with increasing rapidity, as in the cases of ferric chloride and copper chloride, while sometimes a sudden and very marked falling off of transparency occurs at a definite temperature, as in the case of copper acetate and nickel chloride. One of the solutions of this group, potassium permanganate, gains materially in transparency for the wave-length tested, a result due to a gradual decomposition brought about by heating.

\section{GROUP A.}

Solutions showing temporary loss throughout the spectrum.

TABLE II.

COBALT AMMONIUM SULPHATE ( 8 GRMS. IN 300 cc. $\mathrm{H}_{2} \mathrm{O}$ ).

\begin{tabular}{|c|c|c|c|c|c|c|c|}
\hline \multicolumn{8}{|c|}{ Wave-length $0.6867 \mu$} \\
\hline \multirow{2}{*}{ Temperature } & $18^{\circ}$ & $28^{\circ}$ & $38^{\circ}$ & $48^{\circ}$ & $59^{\circ}$ & $69^{\circ}$ & $78^{\circ}$ \\
\hline & $\left\{22^{\circ}\right.$ & $31^{\circ}$ & $42^{\circ}$ & $56^{\circ}$ & $64^{\circ}$ & $74^{\circ}$ & $82^{\circ}$ \\
\hline Transmission & 0.76 & 0.76 & 0.69 & 0.68 & 0.65 & 0.64 & 0.61 \\
\hline \multicolumn{8}{|c|}{ Wave-length $0.5^{89} 6 \mu$} \\
\hline \multirow{2}{*}{ Temperature } & $\int 19^{\circ}$ & $28^{\circ}$ & $38^{\circ}$ & $48^{\circ}$ & $58^{\circ}$ & $68^{\circ}$ & $78^{\circ}$ \\
\hline & $23^{\circ}$ & $33^{\circ}$ & $42^{\circ}$ & $52^{\circ}$ & $61^{\circ}$ & $72^{\circ}$ & $81^{\circ}$ \\
\hline Transmission & 0.58 & 0.57 & 0.56 & 0.56 & 0.52 & 0.51 & 0.50 \\
\hline
\end{tabular}


TABLE II. (continued).

\begin{tabular}{|c|c|c|c|c|c|c|c|}
\hline \multicolumn{8}{|c|}{ Wave-length $0.5500 \mu$} \\
\hline Temperature & $20^{\circ}$ & $30^{\circ}$ & $\left\{\begin{array}{l}39^{\circ} \\
38^{\circ}\end{array}\right.$ & $\left.\begin{array}{l}49^{\circ} \\
50^{\circ}\end{array}\right\}$ & $60^{\circ}$ & $71^{\circ}$ & $80^{\circ}$ \\
\hline Transmission & 0.21 & 0.20 & 0.19 & 0.19 & 0.17 & 0.15 & 0.15 \\
\hline \multicolumn{8}{|c|}{ Wave-length $0.5200 \mu$} \\
\hline Temperature & $20^{\circ}$ & $31^{\circ}$ & $40^{\circ}$ & $50^{\circ}$ & $60^{\circ}$ & $69^{\circ}$ & $80^{\circ}$ \\
\hline Transmission & 0.07 & 0.06 & 0.06 & 0.05 & 0.05 & 0.05 & 0.04 \\
\hline \multicolumn{8}{|c|}{ Wave-length $0.4900 \mu$} \\
\hline Temperature & $21^{\circ}$ & $30^{\circ}$ & $40^{\circ}$ & $49^{\circ}$ & $61^{\circ}$ & $69^{\circ}$ & $80^{\circ}$ \\
\hline Transmission & 0.07 & 0.067 & 0.05 & 0.06 & 0.06 & 0.05 & 0.05 \\
\hline \multicolumn{8}{|c|}{ Wave-length $0.4700 \mu$} \\
\hline Temperature & $20^{\circ}$ & $31^{\circ}$ & $40^{\circ}$ & $49^{\circ}$ & $60^{\circ}$ & $70^{\circ}$ & $80^{\circ}$ \\
\hline Transmission & 0.14 & 0.12 & 0.11 & 0.10 & 0.10 & 0.10 & 0.10 \\
\hline \multicolumn{8}{|c|}{ Wave-length $0.4550 \mu$} \\
\hline Temperature & $22^{\circ}$ & $30^{\circ}$ & $39^{\circ}$ & $50^{\circ}$ & $60^{\circ}$ & $69^{\circ}$ & $80^{\circ}$ \\
\hline Transmission & 0.08 & 0.07 & 0.07 & 0.07 & 0.06 & 0.05 & 0.05 \\
\hline
\end{tabular}

The above results for cobalt ammonium sulphate, which may be regarded as typical, are indicated graphically by means of both forms of diagram in Fig. 3 .

In this and in all solutions tested, excepting those which suffered permanent change as the result of heating, the isochromatic diagrams (within the limits of accuracy) were straight lines.
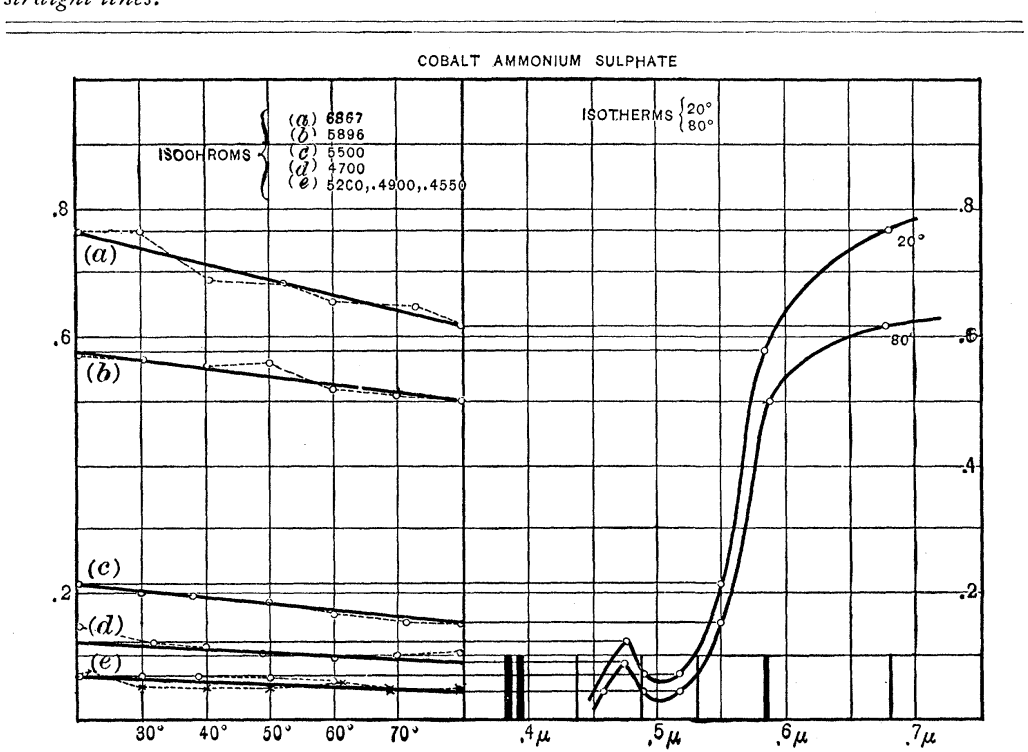

Fig. 3. 
TAble III.

POTASSIUM BICHROMATE (4 GRMS. IN 300 cC. $\mathrm{H}_{2} \mathrm{O}$ ).

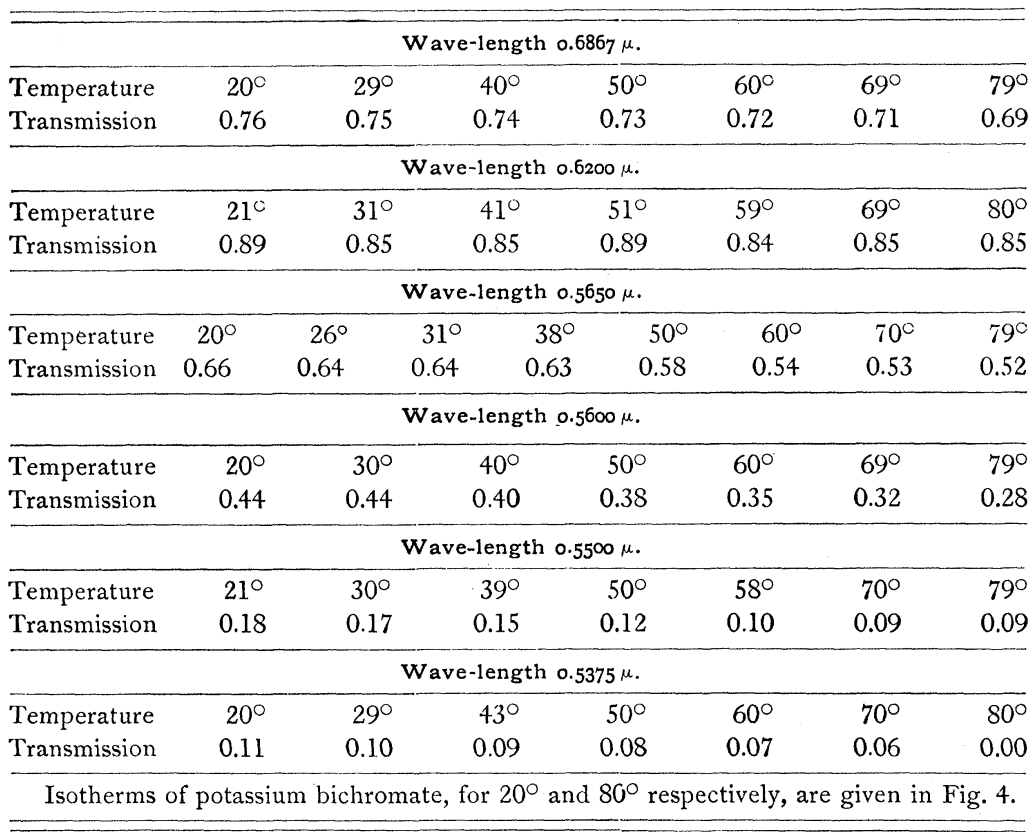

POTASSIUM BICHROMATE

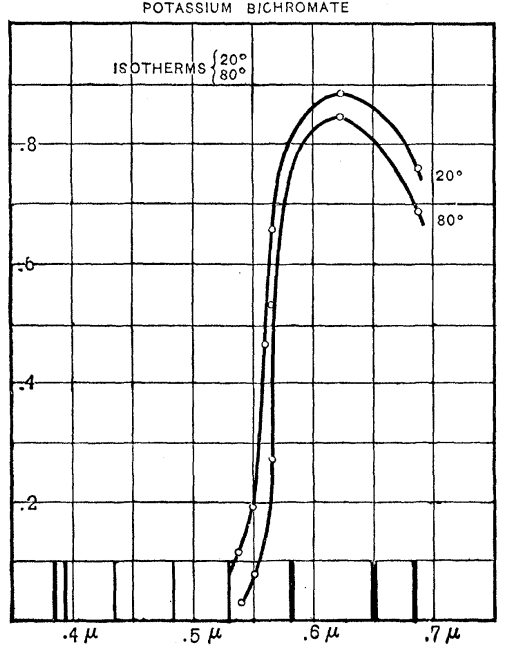

Fig. 4.
POTASSIUM CHROMATE

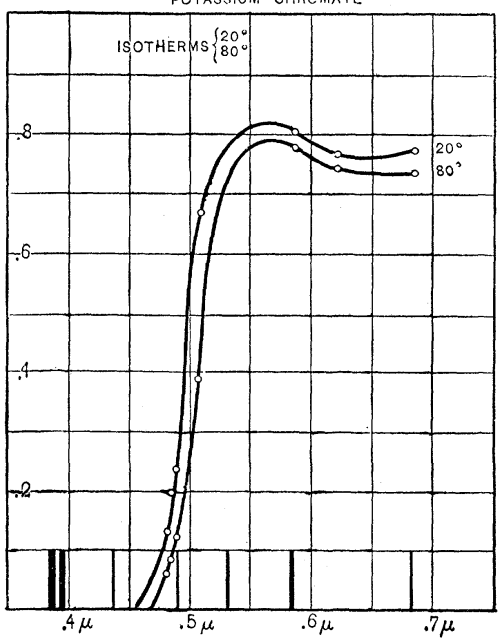

Fig. 5 . 
TABLE IV.

POTASSIUM CHROMATE ${ }^{1}$ ( 4 GRMS. IN 300 cc. $\mathrm{H}_{2} \mathrm{O}$ ).

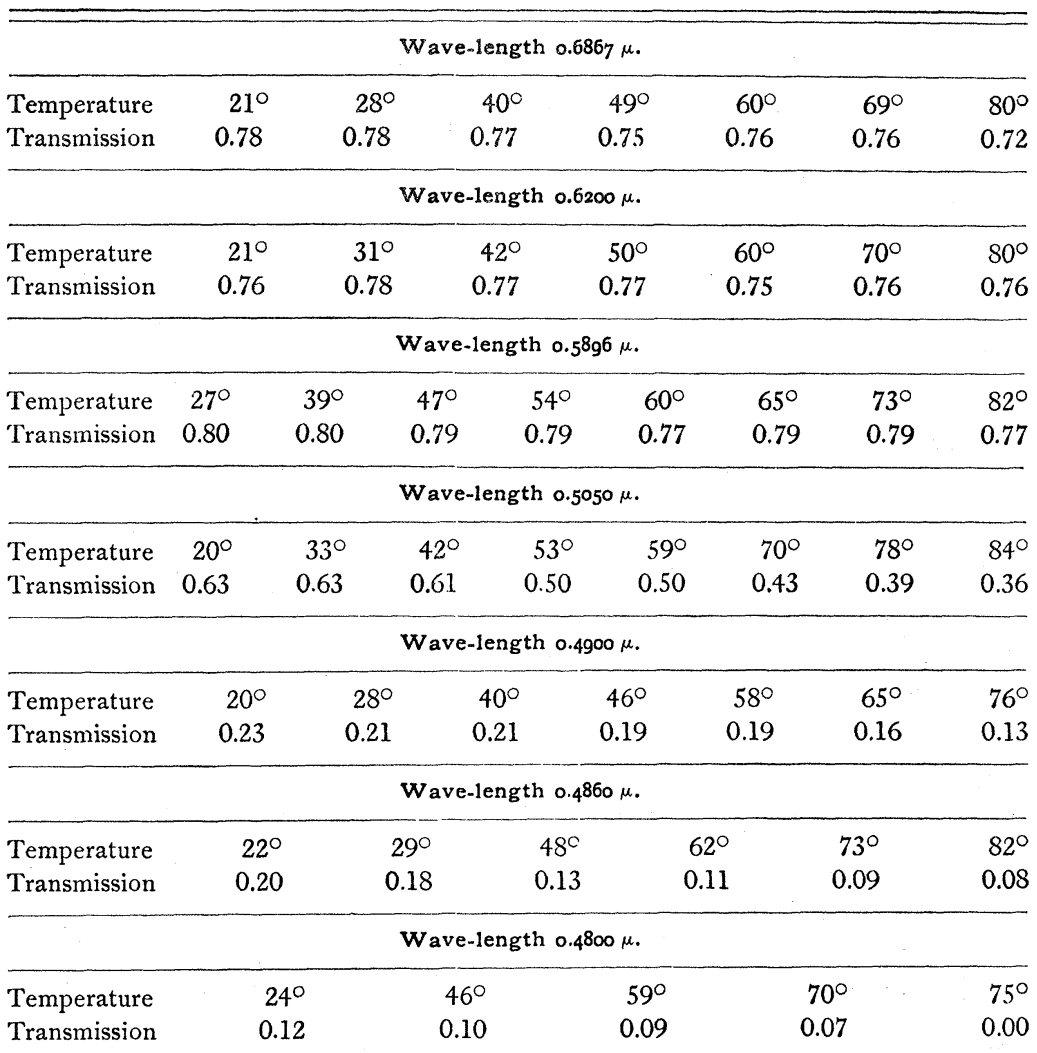

Isotherms of potassium chromate, for $20^{\circ}$ and $80^{\circ}$ respectively, are given in Fig. 5.

1 Potassium chromate forms an intermediate member of Groups A and B. In one of the regions explored $(0.6200 \mu-0.5900 \mu)$, the influence of temperature was almost imperceptible. 
GROUP B.

Solutions showing temporary loss throughout a portion of the spectrum.

TABLE V.

SODIUM BICHROMATE ( 4 GRMS. IN 450 cc. $\mathrm{H}_{2} \mathrm{O}$ ).

\begin{tabular}{|c|c|c|c|c|c|c|c|}
\hline \multicolumn{8}{|c|}{ Wave-length $0.6867 \mu$} \\
\hline Temperature & $22^{\circ}$ & $30^{\circ}$ & $40^{\circ}$ & $50^{\circ}$ & $60^{\circ}$ & $69^{\circ}$ & $80^{\circ}$ \\
\hline Transmission & 0.74 & 0.78 & 0.80 & 0.78 & 0.72 & 0.73 & 0.74 \\
\hline \multicolumn{8}{|c|}{ Wave-length $0.6200 \mu$} \\
\hline Temperature & $22^{\circ}$ & $29^{\circ}$ & $39^{\circ}$ & $50^{\circ}$ & $59^{\circ}$ & $69^{\circ}$ & $80^{\circ}$ \\
\hline Transmission & 0.82 & 0.83 & 0.83 & 0.83 & 0.83 & 0.84 & 0.83 \\
\hline \multicolumn{8}{|c|}{ Wave-length $0.5^{8} g^{6} \mu$. } \\
\hline Temperature & $20^{c}$ & $30^{\circ}$ & $40^{\circ}$ & $50^{\circ}$ & $59^{\circ}$ & $70^{\circ}$ & $80^{\circ}$ \\
\hline Transmission & 0.71 & 0.71 & 0.73 & 0.71 & 0.72 & 0.71 & 0.71 \\
\hline \multicolumn{8}{|c|}{ Wave-length $0.5500 \mu$} \\
\hline Temperature & $21^{\circ}$ & $30^{\circ}$ & $40^{\circ}$ & $50^{\circ}$ & $60^{\circ}$ & $70^{\circ}$ & $79^{\circ}$ \\
\hline Transmission & 0.51 & 0.48 & 0.47 & 0.44 & 0.41 & 0.38 & 0.37 \\
\hline \multicolumn{8}{|c|}{ Wave-length $0.535^{\circ} \mu$} \\
\hline Temperature & $22^{\circ}$ & $30^{\circ}$ & $39^{\circ}$ & $49^{\circ}$ & $59^{\circ}$ & $71^{\circ}$ & $80^{\circ}$ \\
\hline Transmission & 0.13 & 0.11 & 0.10 & 0.09 & 0.08 & 0.09 & 0.07 \\
\hline \multicolumn{8}{|c|}{ Wave-length $0.5^{2} 30 \mu$} \\
\hline Temperature & $21^{\circ}$ & $29^{\circ}$ & $39^{\circ}$ & $49^{\circ}$ & $61^{\circ}$ & $70^{\circ}$ & $79^{\circ}$ \\
\hline Transmission & 0.10 & 0.09 & 0.08 & 0.08 & 0.07 & 0.06 & 0.05 \\
\hline
\end{tabular}

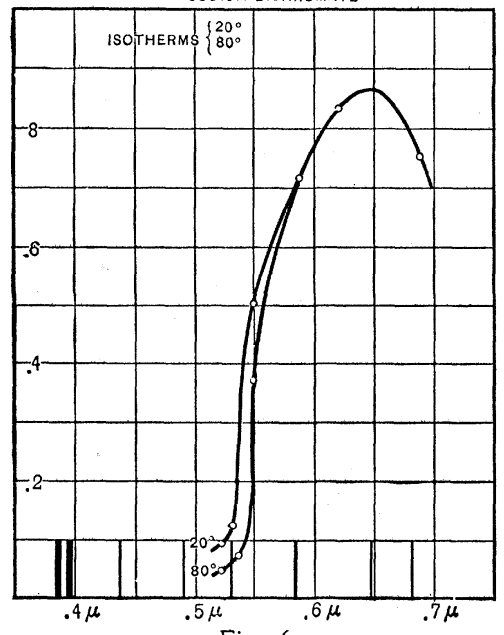

Fig. 6.

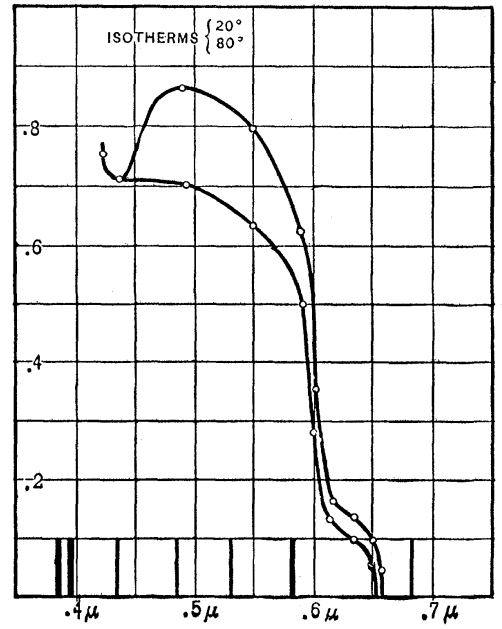

Fig. 7. 
No. 5.] THE TRANSPARENCY OF SOLUTIONS.

TABLE VI.

COPPER SULPHATE ( 8 GRMS. IN 300 cC. $\mathrm{H}_{2} \mathrm{O}$ ).

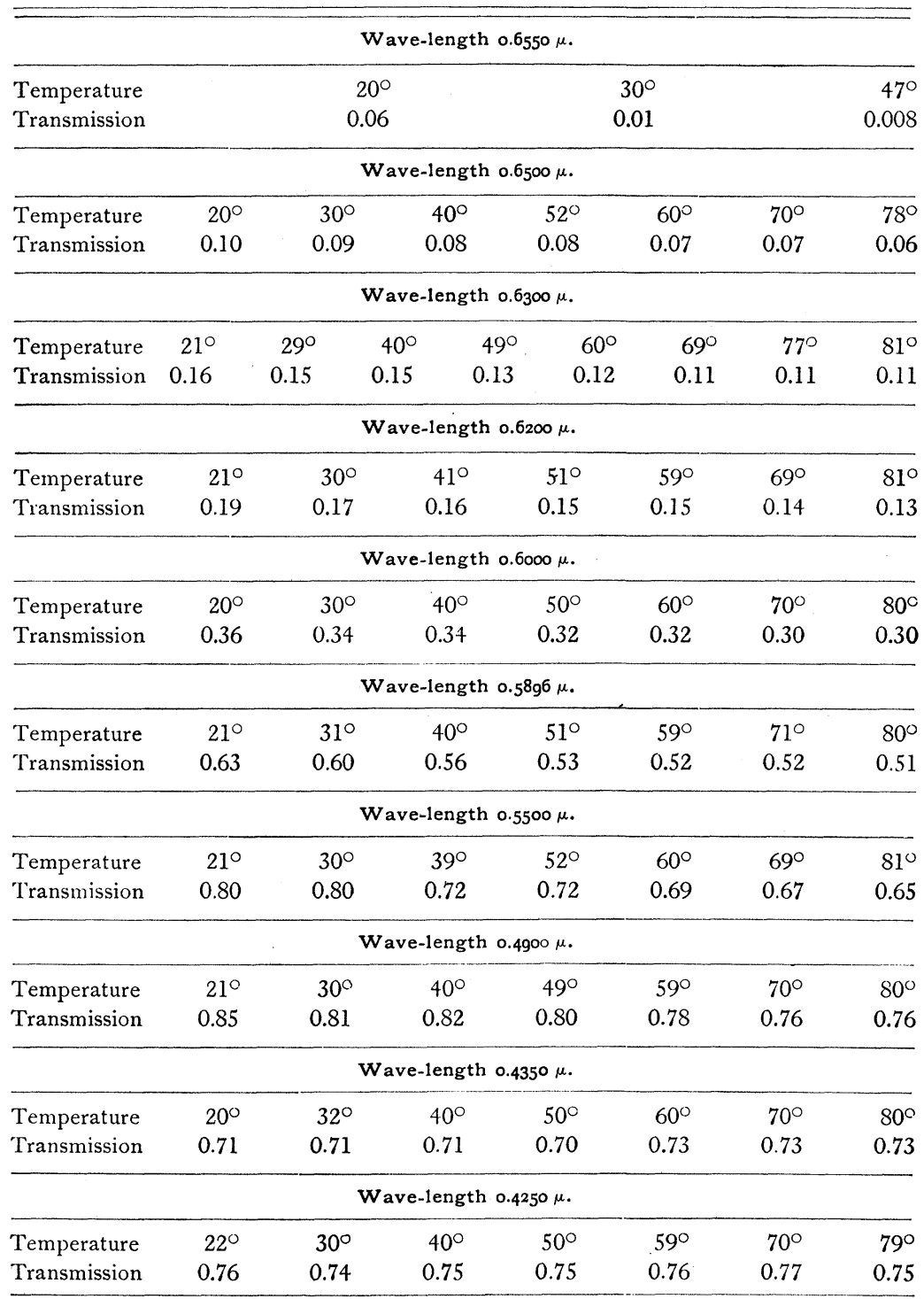

Isotherms of copper sulphate, for $20^{\circ}$ and $80^{\circ}$ respectively, are given in Fig. 7 . 
TABLE VII.

CHROMIC SUlPHATE (7 GRMs. IN 800 cC. $\mathrm{H}_{2} \mathrm{O}$ ).

\begin{tabular}{|c|c|c|c|c|c|c|c|}
\hline \multicolumn{8}{|c|}{ Wave-length $0.6867 \mu$} \\
\hline Temperature & $22^{\circ}$ & $30^{\circ}$ & $40^{\circ}$ & $49^{\circ}$ & $61^{\circ}$ & $69^{\circ}$ & $79^{\circ}$ \\
\hline Transmission & 0.52 & 0.50 & 0.49 & 0.49 & 0.48 & 0.44 & 0.43 \\
\hline \multicolumn{8}{|c|}{ Wave-length $0.6200 \mu$. } \\
\hline Temperature & $20^{\circ}$ & $29^{\circ}$ & $39^{\circ}$ & $49^{\circ}$ & $59^{\circ}$ & $71^{\circ}$ & $80^{\circ}$ \\
\hline Transmission & 0.25 & 0.24 & 0.24 & 0.23 & 0.22 & 0.22 & 0.21 \\
\hline \multicolumn{8}{|c|}{ Wave-length $0.5896 \mu$} \\
\hline Temperature & $21^{\circ}$ & $29^{\circ}$ & $30^{\circ}$ & $39^{\circ}$ & $60^{\circ}$ & $70^{\circ}$ & $79^{\circ}$ \\
\hline Transmission & 0.13 & 0.12 & 0.12 & 0.11 & 0.11 & 0.10 & 0.10 \\
\hline \multicolumn{8}{|c|}{ Wave-length $0.5500 \mu$} \\
\hline Temperature & $20^{\circ}$ & $30^{\circ}$ & $39^{\circ}$ & $50^{\circ}$ & $60^{\circ}$ & $69^{\circ}$ & $80^{\circ}$ \\
\hline Transmission & 0.14 & 0.14 & 0.13 & 0.13 & 0.12 & 0.12 & 0.12 \\
\hline \multicolumn{8}{|c|}{ Wave-length $0.5200 \mu$} \\
\hline Temperature & $22^{\circ}$ & $30^{\circ}$ & $41^{\circ}$ & $51^{\circ}$ & $60^{\circ}$ & $70^{\circ}$ & $80^{\circ}$ \\
\hline Transmission & 0.37 & 0.37 & 0.37 & 0.37 & 0.37 & $0: 37$ & 0.37 \\
\hline \multicolumn{8}{|c|}{ Wave-length $0.4700 \mu$} \\
\hline Temperature & $20^{\circ}$ & $31^{\circ}$ & $40^{\circ}$ & $50^{\circ}$ & $60^{\circ}$ & $70^{\circ}$ & $80^{\circ}$ \\
\hline Transmission & 0.56 & 0.56 & 0.56 & 0.54 & 0.50 & 0.47 & 0.44 \\
\hline \multicolumn{8}{|c|}{ Wave-1ength 0.4350} \\
\hline Temperature & $22^{\circ}$ & $30^{\circ}$ & $40^{\circ}$ & $50^{\circ}$ & $59^{\circ}$ & $71^{\circ}$ & $80^{\circ}$ \\
\hline Transmission & 0.45 & 0.43 & 0.43 & 0.42 & 0.42 & 0.39 & 0.38 \\
\hline
\end{tabular}

Isotherms of chromic sulphate, for $20^{\circ}$ and $80^{\circ}$ respectively, are given in Fig. 8.

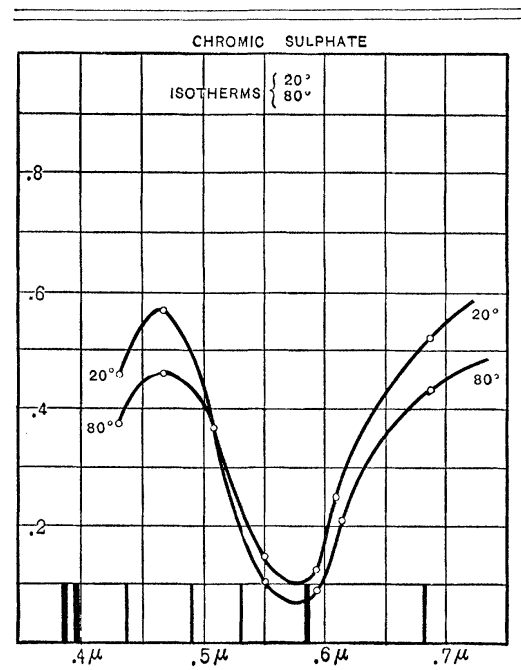

Fig. 8.

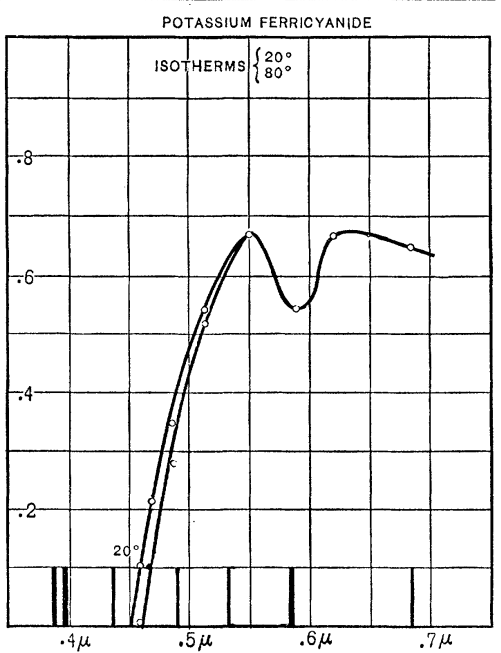

Fig. 9. 
Table ViII.

POTASSIUM FERRICYANIDE (4 GRMS. IN 150 cC. $\mathrm{H}_{2} \mathrm{O}$ ).

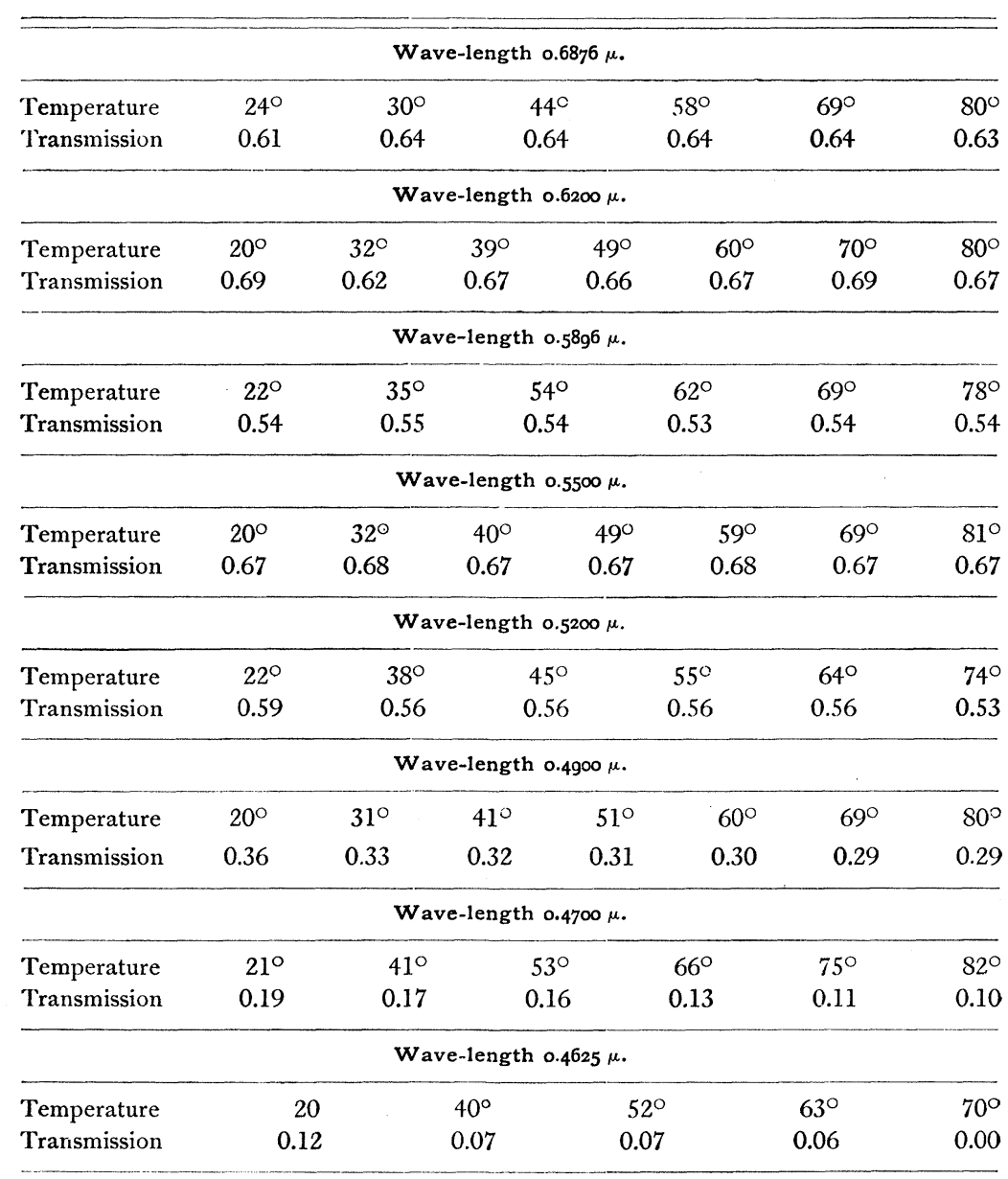

Isotherms of potassium ferricyanide, for $20^{\circ}$ and $80^{\circ}$ respectively, are given in Fig. 9. 
GROUP C.

Liquids unaffected by change of temperature.

TABLE IX

DISTILLED WATER.

\begin{tabular}{|c|c|c|c|c|c|c|c|}
\hline \multicolumn{8}{|c|}{ Wave-length $0.6867 \mu$. } \\
\hline Temperature & $22^{\circ}$ & $30^{\circ}$ & $40^{\circ}$ & $50^{\circ}$ & $60^{\circ}$ & $70^{\circ}$ & $80^{\circ}$ \\
\hline Transmission & 0.82 & 0.82 & 0.83 & 0.83 & 0.83 & 0.83 & 0.83 \\
\hline \multicolumn{8}{|c|}{ Wave-1ength $0.5200 \mu$} \\
\hline Temperature & $22^{\circ}$ & $29^{\circ}$ & $40^{\circ}$ & $49^{\circ}$ & $59^{\circ}$ & $69^{\circ}$ & $80^{\circ}$ \\
\hline Transmission & 0.72 & 0.73 & 0.72 & 0.72 & 0.71 & 0.71 & 0.71 \\
\hline \multicolumn{8}{|c|}{ Wave-length $0.4250 \mu$} \\
\hline Temperature & $20^{\circ}$ & $30^{\circ}$ & $40^{\circ}$ & $50^{\circ}$ & $60^{\circ}$ & $70^{\circ}$ & $80^{\circ}$ \\
\hline Transmission & 0.81 & 0.82 & 0.81 & 0.82 & 0.82 & 0.83 & 0.82 \\
\hline
\end{tabular}

TABLE X.

COCHINEAI, (3 GRMS. IN 600 cC. $\mathrm{H}_{2} \mathrm{O}$ ).

\begin{tabular}{|c|c|c|c|c|c|c|c|}
\hline \multicolumn{8}{|c|}{ Wave-length $0.6867 \mu$. } \\
\hline Temperature & $23^{\circ}$ & $31^{\circ}$ & $41^{\circ}$ & $49^{\circ}$ & $59^{\circ}$ & $70^{\circ}$ & $80^{\circ}$ \\
\hline Transmission & 0.76 & 0.76 & 0.76 & 0.75 & 0.75 & 0.75 & 0.76 \\
\hline \multicolumn{8}{|c|}{ Wave-length $0.6200 \mu$. } \\
\hline Temperature & $20^{\circ}$ & $30^{\circ}$ & $40^{\circ}$ & $50^{\circ}$ & $60^{\circ}$ & $70^{\circ}$ & $80^{\circ}$ \\
\hline Transmission & 0.33 & 0.35 & 0.34 & 0.34 & 0.35 & 0.34 & 0.34 \\
\hline \multicolumn{8}{|c|}{ Wave-length $0.58 g^{6} \mu$. } \\
\hline Temperature & $22^{\circ}$ & $30^{\circ}$ & $40^{\circ}$ & $50^{\circ}$ & $60^{\circ}$ & $70^{\circ}$ & $80^{c}$ \\
\hline Transmission & 0.18 & 0.17 & 0.17 & 0.16 & 0.16 & 0.17 & 0.17 \\
\hline \multicolumn{8}{|c|}{ Wave-length $0.535^{\circ} \mu$} \\
\hline Temperature & $20^{\circ}$ & $30^{\circ}$ & $40^{\circ}$ & $50^{\circ}$ & $59^{\circ}$ & $70^{\circ}$ & $80^{\circ}$ \\
\hline Transmission & 0.40 & 0.41 & 0.40 & 0.39 & 0.39 & 0.40 & 0.40 \\
\hline
\end{tabular}


TABLE XI.

SODIUM NITRATE ( 4 GRMS. IN $300 \mathrm{cC} . \mathrm{H}_{2} \mathrm{O}$ ).

\begin{tabular}{|c|c|c|c|c|c|c|c|}
\hline \multicolumn{8}{|c|}{ Wave-length $0.6867 \mu$} \\
\hline Temperature & $20^{\circ}$ & $30^{\circ}$ & $40^{\circ}$ & $50^{\circ}$ & $61^{\circ}$ & $70^{\circ}$ & $79^{\circ}$ \\
\hline Transmission & $0.7 \mathrm{~S}$ & 0.79 & 0.79 & 0.80 & 0.80 & 0.80 & 0.80 \\
\hline \multicolumn{8}{|c|}{ Wave-length $0.5500 \mu$} \\
\hline Temperature & $20^{\circ}$ & $30^{\circ}$ & $40^{\circ}$ & $50^{\circ}$ & $60^{\circ}$ & $70^{\circ}$ & $80^{\circ}$ \\
\hline Transmission & 0.88 & 0.88 & 0.86 & 0.86 & 0.84 & 0.84 & 0.86 \\
\hline \multicolumn{8}{|c|}{ Wave-length $0.435^{\circ} \mu$} \\
\hline Temperature & $20^{\circ}$ & $30^{\circ}$ & $40^{\circ}$ & $50^{\circ}$ & $60^{\circ}$ & $70^{\circ}$ & $80^{\circ}$ \\
\hline Transmission & 0.84 & 0.85 & 0.85 & 0.82 & 0.83 & 0.82 & 0.82 \\
\hline
\end{tabular}

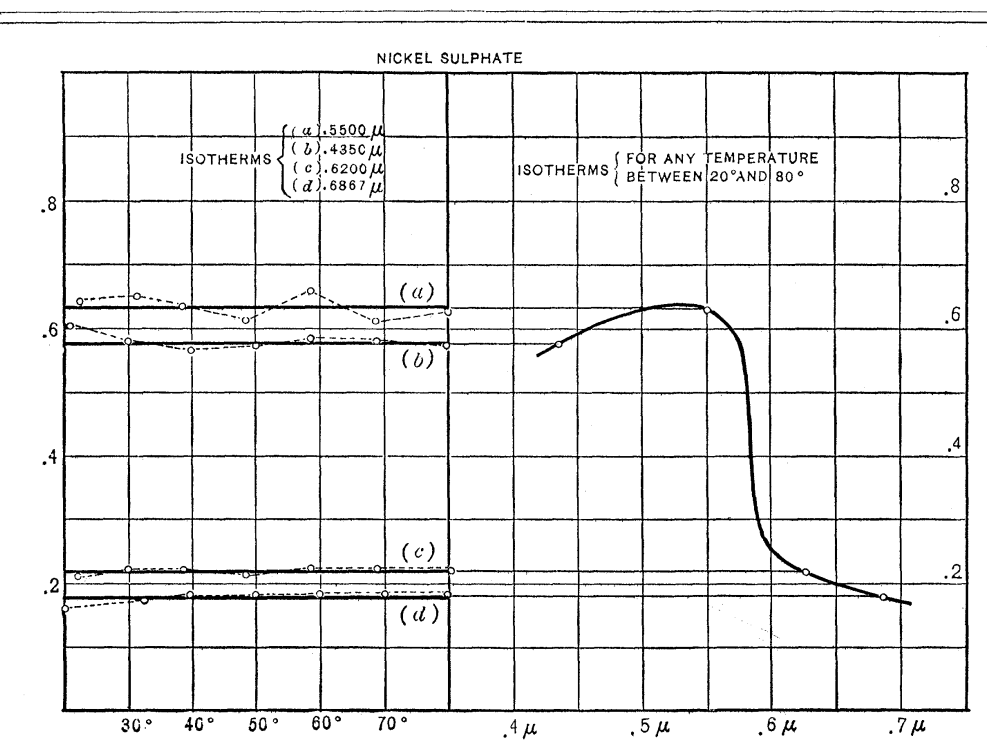

Fig. 10.

TABLE XII.

NICKEL SULPHATE ( 4 GRMS. IN 300 cC. $\mathrm{H}_{2} \mathrm{O}$ ).

\begin{tabular}{lrrrrrrr}
\hline \multicolumn{8}{c}{ Wave-length $0.6867 \mu}$. \\
\hline Temperature & $20^{\circ}$ & $32^{\circ}$ & $40^{\circ}$ & $50^{\circ}$ & $60^{\circ}$ & $70^{\circ}$ & $80^{\circ}$ \\
Transmission & 0.17 & 0.18 & 0.19 & 0.19 & 0.19 & 0.19 & 0.19
\end{tabular}


TABLE XII. (continued).

\begin{tabular}{lrrrrrrrr}
\hline \multicolumn{7}{c}{ Wave-length $0.6200 \mu}$. \\
\hline Temperature & $23^{\circ}$ & $30^{\circ}$ & $39^{\circ}$ & $49^{\circ}$ & $59^{\circ}$ & $69^{\circ}$ & $81^{\circ}$ \\
Transmission & 0.21 & 0.22 & 0.22 & 0.21 & 0.22 & 0.22 & 0.22 \\
\hline \multicolumn{7}{c}{ Wave-length $0.5500 \mu}$. \\
\hline Temperature & $22^{\circ}$ & $31^{\circ}$ & $39^{\circ}$ & $49^{\circ}$ & $59^{\circ}$ & $69^{\circ}$ & $80^{\circ}$ \\
Transmission & 0.64 & 0.65 & 0.63 & 0.61 & 0.66 & 0.61 & 0.62 \\
\hline & \multicolumn{7}{c}{ Wave-length } & $0.4350 \mu$. \\
\hline Temperature & $21^{\circ}$ & $30^{\circ}$ & $40^{\circ}$ & $50^{\circ}$ & $59^{\circ}$ & $69^{\circ}$ & $80^{\circ}$ \\
Transmission & 0.61 & 0.58 & 0.57 & 0.58 & 0.59 & 0.59 & 0.58 \\
\hline
\end{tabular}

A typical example of Group $\mathrm{C}$, in which the isochroms are all horizontal straight lines is nickel sulphate, the characteristics of which are indicated by both forms of diagram in Fig. 10. The observational errors, always large in colorimetric work, are more than usually prominent in this case, particularly in the region $0.55 \mu$, but it is evident from the diagram that in none of the regions studied is the transparency of nickel sulphate modified to a determinable degree by change of temperature.

GROUP D.

Solutions suffering permanent change of color as the result of heating.

TABLE XIII.

COPPER ACETATE (4 GRMS. IN 300 cC. $\mathrm{H}_{2} \mathrm{O}$ ).

\begin{tabular}{|c|c|c|c|c|c|c|c|c|}
\hline Temperature & $22^{\circ}$ & $30^{\circ}$ & $39^{\circ}$ & $50^{\circ}$ & $60^{\circ}$ & $70^{\circ}$ & $80^{\circ}$ & $\lambda-0,550$ \\
\hline Transmission & 0.52 & 0.51 & 0.48 & 0.46 & 0.42 & 0.40 & 0.00 & \\
\hline
\end{tabular}

TABLE XIV.

FERRIC CHLORIDE ( 4 GRMS. IN 150 cC. $\mathrm{H}_{2} \mathrm{O}$ ).

$\left.\begin{array}{lrrrrr}\hline \text { Temperature } & 24^{\circ} & 38^{\circ} & 41^{\circ} & 50^{\circ} & 60^{\circ} \\ \text { Transmission } & 0.15 & 0.14 & 0.13 & 0.07 & 0.00\end{array}\right\} \lambda=0.505 \mu$.


TABLE XV.

POTASSIUM PERMANGANATE ( 1 GRM. IN 1000 cC. $\mathrm{H}_{2} \mathrm{O}$ ).

\begin{tabular}{|c|c|c|c|c|c|c|c|c|}
\hline Temperature & $20^{\circ}$ & $30^{\circ}$ & $40^{\circ}$ & $50^{\circ}$ & $59^{\circ}$ & $69^{\circ}$ & $80^{\circ}$ & $\lambda=0.620 \mu$ \\
\hline Transmission & 0.27 & 0.35 & 0.37 & 0.39 & 0.41 & 0.42 & 0.49 & \\
\hline
\end{tabular}

TABLE XVI.

COPPER CHLORIDE ( 4 GRMS. IN 300 cC. $\mathrm{H}_{2} \mathrm{O}$ ).

\begin{tabular}{|c|c|c|c|c|c|c|}
\hline Temperature & $21^{\circ}$ & $29^{\circ}$ & $40^{\circ}$ & $50^{\circ}$ & $\left.60^{\circ}\right)$ & $\lambda=0.470 \mu$. \\
\hline Transmission & 0.61 & 0.58 & 0.54 & 0.43 & 0.00 & \\
\hline
\end{tabular}

TABLE XVII.

NICKEL CHLORIDE (4 GRMS. IN 300 CC. $\mathrm{H}_{2} \mathrm{O}$ ).

$\left.\begin{array}{lrrrrr}\hline \text { Temperature } & 20^{\circ} & 30^{\circ} & 40^{\circ} & 50^{\circ} & 60^{\circ} \\ \text { Transmission } & 0.12 & 0.12 & 0.11 & 0.09 & 0.00\end{array}\right\} \lambda=0.550 \mu$.

The results of the above measurements upon Group $\mathrm{D}$ are embodied in the diagrams of Fig. 11.

With reference to the results given in numerical and graphical form in this paper, it is probably not without significance to note that in general the influence of a rise of temperature upon the color of pigments and of solutions is the same. The tendency in both cases is towards increased absorption, the loss of transmitting power being selective rather than of uniform distribution throughout the visible spectrum. It is of interest, moreover, to note from Table IX. that water itself suffers no loss of transparency and no appreciable change of color when heated.

From a more detailed study of various solutions, especially of the group considered last, much that is interesting and important might doubtless be derived. The importance, likewise, of making measurements of this character upon solutions possessing definite absorption bands, to which reference has been made in a previous paragraph, is obvious. The investigation might be extended with 
great interest also to the infra-red and to the ultra-violet, in which important regions of the spectrum the transmitting power of very many substances, so far as quantitive measurements are concerned, to say nothing of the influence of temperature upon that

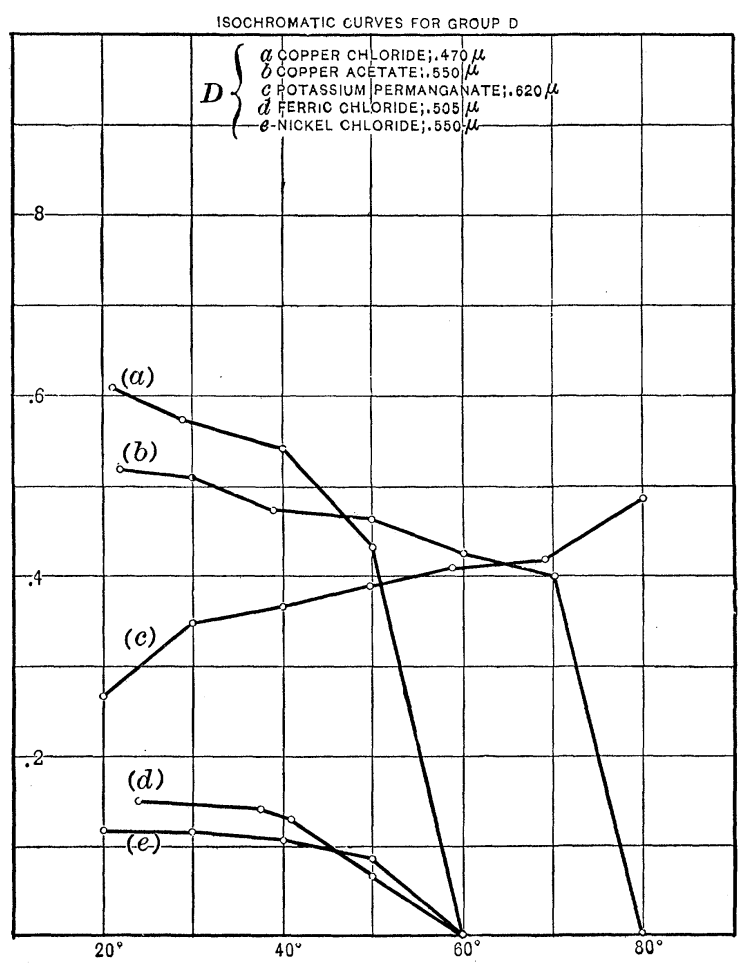

Fig. 11.

property, remains as yet unknown. If the incomplete experiments described here serve to indicate, even dimly, the direction to be given to further research in this field, the publication of them will have fulfilled its purpose.

August, 1894. 